\title{
Rethinking Cadar Banning in Indonesia's Higher Education: Questioning Freedom of Religion and Positioning Fear of Radicalism
}

\author{
Budi Kurniawan ${ }^{1 *}$ \\ ${ }^{1}$ Sebelas Maret University, Surakarta, Indonesia
}

\begin{abstract}
Several universities in Indonesia began to impose a ban on wearing the cadar in the campus environment. Campus policy enacted banning the cadar with various arguments, including the ideological and security reasons. The campus environment is suspected by some people to be a nest of radicalism. Consequently, many things that associated with radicalism is experiencing controlling action as the process of prevention. Not only universities, but also some Islamic State colleges began to enact this policy. Moderate Islam to be one of the arguments of the policy enforcement. The blurb brings up a question of religious freedom will be on campus. This paper analyses the policy of cadar banning on campus in the perspective of religious freedom and law in Indonesia. Socio-political context is also important to analysed relations with this policy. Indonesia as a democratic State and the upholding of human rights, including rights in religion should review and be critical of the policy of banning the cadar. Pancasila and the spirit of diversity should be used as reference in fostering the harmony of the nation, including in the campus environment.
\end{abstract}

\section{Introduction and literature review}

The debate over the use of cadar in public spaces, especially in universities, appears in the midst of society. In the midst of a wave of radical stigmatization in universities in Indonesia, several higher educational institutions began to implement a cadar usage policy. The cadar that is associated with the representation of the Islamic religious understanding which is considered radical makes various parties issue policies related to this matter. In addition, various campuses that prohibit the use of cadar while on campus have their own rationality to legitimize their policies. Although the policy constitutes campus internal autonomy in regulating and managing a climate that is considered conducive in its environment, it does not mean that the campus can ignore the human rights that exist in every student who studies in the environment. One of the human rights that has the potential to be violated in the application of the policy is the personal right to freely adhere to and practice the teachings of religion and belief.

The cadar is a veil cloth that covers the entire face except for the eye [1]. The use of cadar in the public space from the perspective of social science has various interrelated

* Corresponding author: budikurniawan1999@gmail.com 
dimensions, including the dimensions of culture, religion, politics, etc. [2]. In the Indonesian context, the wearing of the cadar is more dominant regarding religious motives or the practice of religious understanding which she believes in. For those who believe, the cadar is one of the Islamic obligatory. Indonesia as a country with a majority of Muslim population throughout the world is a place to meet and intersect various schools of Islamic understanding, including in the use of this veil. The use of cadar is one of the mirrors of Islamic conservatism adopted by certain circles [3]. With the diversity of religious understandings that exist, the State guarantees every citizen to get various rights, one of which is to practice the teachings s/he believes in, as long as it does not interfere with the rights of others [4].

When compared with European countries which include banning the use of cadar in public spaces, such as in France, the policy of prohibiting the wearing of cadar in public spaces such as in Indonesia must be reviewed. In the French context, the laicite context is known, namely the principle of secularism that applies in the country [5]. Public space must be neutral from religious symbols and the state severely limits the role of religion in public space. The discourse of Islamophobia is becoming a mainstream in European countries which can be attributed to the rise of populist issues in Europe calling for anti-immigrant campaigns and Islamic minority discrimination [6]. In contrast to this, Indonesia adheres to the principles of Pancasila in which in its first paragraph guarantees the principles of religiosity in society. The right to freedom of religion or belief is guaranteed by the Pancasila, the UUD 1945 and related legal regulations. Indonesia is neither a religious state nor a secular state. The context of banning the cadar becomes a policy that needs to be reviewed, especially in public spaces such as on campus. A study proves that the flow of radicalism is also about educated groups such as students and lecturers [7]. This evidence is the main argument associated with the issue of deradicalization on campus that have an impact on cadar banning.

The campus that had imposed the ban on wearing cadar for students was the faculty of agriculture at the Sebelas Maret University, Surakarta [8]. The dean of the faculty of agriculture at the university issued a letter regulating dress ethics on campus. Prohibition of wearing the cadar is accompanied by the regulation of other dress ethics, such as the prohibition on wearing T-shirts and flip-flops and haircuts like punk children in the faculty environment. The prohibition is intended to maintain the good communication between students and lecturers. However, the regulation was not valid for a long time, because the rector of Sebelas Maret University did clarification and evaluation so that the letter issued by the dean was automatically no longer valid.

Other campus that has imposed a ban on wearing a cadar for students is the Sunan Kalijaga State Islamic University of Yogyakarta (UIN Sunan kalijaga). The Rector of UIN Sunan Kalijaga issued a decree related to the ban on wearing cadar on campus for students [9]. Because he was feared to the students who used Cadar adhered to the anti-pancasila Islamic ideology. He also claimed the regulation was to prevent students from following a distorted ideology and becoming a "terrorist wife". The prohibition policy was followed up by coaching 42 students who were registered as students with cadar on campus. The coaching was carried out by interdisciplinary lecturers who claimed to aim to make the students aware. If in 9 times counselling the student remains using cadar, the student will be expelled from campus [10]. Because it caused controversy, after some time, the policy was revoked in order to maintain a conducive academic climate [11]. Many parties consider the policy to be discriminatory against students, including criticism coming from religious organizations in Yogyakarta, DPR, and other institutions. Although the Minister of Technology and Higher Education Research does not agree with the prohibition policy, the policy is entirely a campus internal autonomy. The ministry does not deal with such problems and only in the academic domain [12]. 
In addition, there are still many campuses that issue specific policies related to wearing cadar in the academic environment. In Jakarta, a pharmacy lecturer at the Syarif Hidayatullah State Islamic University resigned from his profession due to being appealed by his rector to open his cadar when teaching because it was considered disruptive to the teaching and learning process [13]. In Semarang, Walisongo State Islamic University has imposed a ban on wearing cadar in the academic environment [14]. Sumayyah, a student of the Indonesia Maju School of Health Sciences (STIKIM) Jakarta who had just gone to college for a few days in the early years of entering the campus was forced to resign because of pressure from some parties on campus to take off her cadar [15]. Hayati Syafri, an English lecturer at the Faculty of Tarbiyah and Teaching Sciences of the IAIN Bukittinggi, was disabled because of using cadar in campus [16]. Repression related to cadar also occurred at Pamulang University in Tangerang and the Lambung Mangkurat University in Banjarmasin [17].

What is being studied further is why many campuses especially with the status of state Islamic higher education institution (PTKIN) under the Ministry of Religious Affairs are vocal in implementing the ban on wearing the cadar on campus. The state, in this case, the Ministry of Religious Affairs through various state islamic higher education carry out the mainstreaming of Islamic schools of thought [18]. Vernacular Islam which later became the distinction of state Islamic universities led to various institutional policies derived from the same core spirit. The policy of prohibition of the cadar, especially in the case of UIN Sunan Kalijaga which argues to prevent radicalism and favoritism it as the "official mazhab" is a phenomenon that must be further analysed in the perspective of human rights.

\section{Objective of the study}

This study is to analyse the state favoritism for certain religious thought that causes other religious schools or thought to become victims of discrimination that violates human right. That is the main focus of this study. The campus which has an inclusive perspective towards various diversity of Islamic thought is tested for its consistency in dealing with cadar and radicalism discourse. In the midst of radicalism issues in higher education, this politics can be behind on this issues.

\section{Methodology}

The study used a descriptive analytic approach. This study seeks to examine the policy of prohibiting cadar in the campus environment, especially state-owned campuses from the perspective of human rights and trying to find relations with the existing religious and political context. The main data sources come from the available news and literature studies relating to the context of the ban on wearing cadar. This study attempts to describe and analyse the policy discourses of cadar ban on campuses.

\section{Discussion}

Ideologically, Indonesia recognizes the principle of religiosity in the life of nation and state. Guarantee of religious freedom in Indonesia has been constitutionally regulated. In article 29 paragraph 2 of the UUD 1945 stated: "the State guarantees the independence of each citizen to embrace their religion and to worship according to their religion and belief" [19]. Article 28E paragraph 1 of the UUD 1945 reads "Every person is free to embrace religion and worship according to his religion, choose education and teaching, choose a job, choose citizenship, choose a place to live in the territory of the State and leave it, and have the right to return" [20]. Law No.39 of 1999 also guarantees religious freedom as derogable rights 
[21]. In addition, there are still many national and international human rights instruments that accommodate religious freedom.

The issue of radicalism can be as rationality in the application of the policy of prohibiting cadar on campus. But this policy is contrary to the principles of human rights that apply in Indonesia in the public sphere. Especially in the context of state-owned campus, it should be able to accommodate various religious understanding [22]. State schools should be the place for planting and applying multicultural values that shape a person who has a tolerant soul [23]. The applicable law in Indonesia applies in a non-discriminatory manner, including in the context of the prohibition of cadar that are not in accordance with the principles of human rights [24]. Existence Religious symbols in the public space are inevitable implications of the implementation of the guarantee of the rights of religious freedom recognized in the Pancasila and the UUD 1945. The problem is that religious symbols that are in the public sphere cannot be separated from the social, political and cultural context accompany it stigmatization of certain religious symbols, as on cadar cases, occurs because it cannot be separated from terror events that use these symbols which are then associated with radicalism and terrorism.

When viewed in the context of the sociopolitical implementation of the ban on cadar, one of them is at UIN Sunan Kalijaga, the current radicalism in universities is being watched by various parties. After the dissolution of Hizb ut-Tahrir Indonesia, the phenomenon of radicalization in universities was anticipated [25]. State campuses carry out prevention and anticipation of current radicalism [26]. Deradicalization by socializing Pancasila as the main state ideology continues to be promoted in Indonesia. State campuses are the main place in the process of deradicalization. In carrying out the process of deradicalization, prior identification has been made of matters relating to radicalism and terrorism. This identification process has the potential to generalize the use of cadar that are used for radical purposes. The cadar is seen as a symbol of the religion that is closed, not interactive, and full of suspicion [27]. Because of security reasons both ideologically and practically, cadar gets special treatment compared to other clothing models.

But the stigmatization wave occurs excessively. The cadar stigma as part of a symbol of radicalism that has the potential to commit acts of terrorism is a major issue on various campuses. This reasoning is one reason for the rector of UIN Sunan Kalijaga to issue a circular related to the formation of the students who use cadar. The assumptions used by him are by making the cadar a religious symbol that has the potential for seeds of radicalism and terrorism [28]. This is one part of the cadar stigmatization process itself. In any context, the cadar can be associated with certain cultural, political, and legal phenomena. However, this phenomenon cannot be generalized in understanding a phenomenon against other phenomena. Religious symbols are often used as identities in acts of terrorism and radicalism. But that does not mean the radical symbol of religion. Anyone who is even a terrorist can use any religious symbol to launch his goal [29]. This cannot be separated from its aim to spread fear in the name of certain religious understandings.

In another context, the prohibition on the use of cadar in various campuses, especially the Islamic campus of the country, shows the power of the state in determining its main choice to defend certain religious understandings. The state favoritism in certain religious understandings can be understood in the phenomenon of the ban on wearing cadar, especially the state islamic campus. The state, in this case, the Ministry of Religious Affairs is actively promoting moderate Islam, namely Islam Nusantara [18]. Islam Nusantara is a new Islamic thought idea that seeks to explore narratives and insights into the richness of Islamic civilization based on the culture of Nusantara. The beginning of the Islam Nusantara discourse became the main theme of the 33rd Muktamar NU in Jombang [30]. Islam Nusantara has a large flow of culture represented by the majority Islamic groups in Indonesia, that are Muhammadiyah and NU [31]. Mainstreaming Islam Nusantara as the 
main model in religious understanding in various Islamic campuses has caused non-moderate understanding of Islam or marginalized such as conservatism to even be considered a threat. Conservatism is not always related to radicalism and terrorism, but the state still creates these discourses that conservatism tends to violence act and suspected to be a radical.

This causes the policies issued to tend to side with people who embrace moderate Islam and make Islam Nusantara as the main perspective and discriminate against other Islamic groups. This discrimination can be seen in this cadar ban policy. Conservatism becomes a flow suspected of having the potential to be radical and terrorist. The state favoritism in this context makes the stateside with certain groups by ignoring the implementation of the rights of others. Although it can be understood that the process is claimed to be part of deradicalization and anticipation of the threat of radicalism to save the Pancasila ideology that certain parties want to replace, but the stigmatization of the cadar as symbols of radicalism and terrorism has the potential to violates human rights. In short, the prohibition of cadar is one of the proofs of the Politics of Islam Nusantara mainstreaming, especially in the state islamic higher education.

\section{Conclusion}

The cadar prohibition by using reasons to prevent the development of radicalism ideology is one part of the cadar stigmatization process. The cadar in a discursive context can be understood in the space of symbolic interaction that experiences various interpretations of meaning. Repression of the wearing of cadar in the public space is contrary to the enforcement of human rights in religion in Indonesia. This study proves the politics of Islam Nusantara mainstreaming that led by state, especially applicate on state islamic higher education behind the deradicalization issues.

\section{References}

1. Indonesian dictionary

2. A. Almila, Intoduction The veil across the globe in politics everyday life and fashion in The Routledge International Handbook to Veils and Veiling (Routledge, New York, 2017)

3. E. Keeble, Politics and Sex: Exploring the Connections between Gender, Sexuality, and the State (Canadian Scholars' Press, Toronto, 2016)

4. A. Wahid, K. Marijan, M. M. Al-Brebesy, Mengurai hubungan agama dan negara (Gramedia Widiasarana Indonesia, Jakarta, 1999)

5. A. Fornerod, Wearing A Veil In The French Context Of Laïcité in The Routledge International Handbook to Veils and Veiling (Routledge, New York, 2017)

6. R. Taras, Xenophobia and Islamophobia in Europe (Edinburgh University Press, Edinburgh, 2012)

7. H. Ali, L. Purwandi, Radicalism rising among educated people? (Alvara Research Center, Jakarta, 2018)

8. Bramantyo, Pelarangan Cadar Jadi Polemik, Rektor UNS: Surat Edaran Dibuat Tergesa-gesa https://news.okezone.com/read/2017/10/05/65/1789535/pelarangancadar-jadi-polemik-rektor-uns-surat-edaran-dibuat-tergesa-gesa (2017) Retrieved August 15, 2018 
9. D. V. Putsanra, Larangan Bercadar di Kampus UIN Yogyakarta Dinilai Diskriminatif https://tirto.id/larangan-bercadar-di-kampus-uin-yogyakarta-dinilai-diskriminatif-cFJq (2018) Retrieved August 1, 2018

10. D. V. Putsanra, Sekitar 42 Mahasiswa Bercadar di UIN Yogya Akan Diberi Bimbingan https://tirto.id/sekitar-42-mahasiswa-bercadar-di-uin-yogya-akan-diberi-bimbingancFHN (2018) Retrieved August 1, 2018

11. A. Mustaqim, Larangan Cadar Dicabut, Mahasiswi UIN Harap Diskriminasi Disetop http://news.metrotvnews.com/read/2018/03/11/843613/larangan-cadar-dicabutmahasiswi-uin-harap-diskriminasi-disetop Retrieved August 15, 2018

12. T. Firmansyah, Ini Kata Menristekdikti Soal Larangan Cadar di Kampus https://www.republika.co.id/berita/dunia-islam/islam-nusantara/18/03/07/p56vi3377ini-kata-menristekdikti-soal-larangan-cadar-di-kampus (2018) Retrieved August 1, 2018

13. M. A. Ridhoi, Rektor UIN ke Dosen: Lepas Cadar atau Berhenti Mengajar https://tirto.id/rektor-uin-ke-dosen-lepas-cadar-atau-berhenti-mengajar-ctLb (2017) Retrieved August 1, 2018

14. A. A. Purbaya, UIN Walisongo Semarang Anggap Mahasisiwi Bercadar Berlebihan https://news.detik.com/jawatengah/3901418/uin-walisongo-semarang-anggapmahasisiwi-bercadar-berlebihan (2018) Retrieved August 15, 2018

15. K. Khalifah, Kronologi Dikeluarkan Mahasiswi Bercadar dari Kampus STIKIM Jakarta, http://m.voa-islam.com/r/26947 (2013) Retrieved August 1, 2018

16. Y. Ratnasari, Ombudsman Minta Larangan Pakai Cadar di IAIN Bukittinggi Dievaluasi, https://tirto.id/ombudsman-minta-larangan-pakai-cadar-di-iain-bukittinggi-dievaluasicGcS Retrieved (2018) August 1, 2018

17. D. Gustian, Kampus yang Larang Penggunaan Cadar https://tirto.id/kampus-yanglarang-penggunaan-cadar-cFNC (2018) Retrieved August 1, 2018

18. R. Armenia, Cegah Radikalisme, Kemenag Kampanyekan Islam Nusantara https://www.cnnindonesia.com/nasional/20160203214507-20-108718/cegah-

radikalisme-kemenag-kampanyekan-islam-nusantara (2016) Retrieved August 15, 2018

19. Undang-Undang Dasar Negara Republik Indonesia 1945

20. Undang-Undang Dasar Negara Republik Indonesia 1945

21. E. Khanif, H. P. Wiratraman (Ed.), Hak Asasi Manusia: Dialektika Universalisme vs Relativisme di Indonesia (LKiS Pelangi Aksara, Yogyakarta, 2017)

22. H. Salim, N. Kailani, N. Azekiyah, Politik Ruang Publik Sekolah: Negosiasi dan Resistensi di Sekolah Menengah Umum Negeri di Yogyakarta (CRCS UGM, Yogyakarta, 2011)

23. M. Hunter-Henin, Law and the wearing of religious symbols: European bans on the wearing of religious symbols in education, Int. J. of Disc. and Law 12, 243-250 (2013)

24. B. Tahzib-Lie, W. C. Durham, T. Lindholm, Kebebasan beragama atau berkeyakinan: seberapa jauh? (Kanisius, Yogyakarta, 2017)

25. L. Egeham, Dibubarkan, HTI Akan Dakwah di Kampus https://www.liputan6.com/news/read/2945490/dibubarkan-hti-akan-dakwah-di-kampus (2017) Retrieved August 15, 2018

26. A. Sumandoyo, Gelombang Stigmatisasi 'Radikalisme' di Perguruan Tinggi Negeri https://tirto.id/gelombang-stigmatisasi-039radikalisme039-di-perguruan-tinggi-negericPq7 (2018) Retrieved August 1, 2018 
27. R. Coolsaet (Ed.), Jihadi Terrorism and the Radicalisation Challenge (Routledge, New York, 2016)

28. R. Coolsaet (Ed.), Jihadi Terrorism and the Radicalisation Challenge (Routledge, New York, 2016)

29. M. D. M. Francis, Why the "Sacred" Is a Better Resource Than "Religion" for Understanding Terrorism, Terr. A. Pol. Viol. 28, 912-927 (2016)

30. A. Mu'ti, F. R. Ulhaq, A. Khoirudin, A. F. Fanani, Kosmopolitanisme Islam Berkemajuan: Catatan Kritis Muktamar Teladan Ke-47 Muhammadiyah di Makasar 2015 (Muhammadiyah University Press, Surakarta, 2016)

31. A. Sahal, M. Aziz (ed.), Islam Nusantara (Mizan, Bandung, 2015) 